
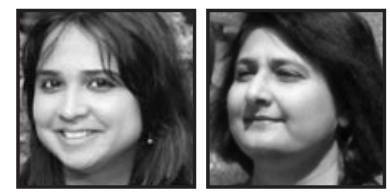

\title{
Using Universal Design for Learning to Construct Inclusive Science Classrooms for Diverse Learners
}

\author{
Neerusha Baurhoo, McGill University \\ Anila Asghar, McGill University
}

\begin{abstract}
This article illuminates academic barriers that students with learning disabilities (LD) face in their science classrooms and the ways in which the Universal Design for Learning (UDL) framework can offer practical ways to promote cognitive access to science education. This article also examines current research on intervention-based practices for students with LD in science classrooms. Drawing on the UDL model, the authors offer a framework for science teachers and practitioners to integrate inclusive practices in their teaching for diverse learners.
\end{abstract}

\section{Introduction}

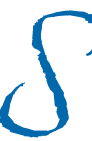

cientific inventions, advancements, and issues are undoubtedly an integral part of our lives in the 21st century. Various issues concerning science and society dominate the media, such as the menace of nuclear weapons; problems concerning climate change and global warming; development of new drugs to treat AIDS and cancer; or recalls of contaminated meat from the market. These issues, amongst others, affect all individuals either positively (e.g., new drugs to treat diseases) or negatively (e.g., contaminated meat causes health issues and deaths). For these reasons, all individuals have to make critical science-driven decisions to improve their own as well as their community's well-being. Our daily reliance on scientific and technological advancements has led policy developers, science educators, 
and scientists to conclude that all students need to develop meaningful scientific literacy (Feinstein, 2011; Holbrook \& Rannikmae, 2009). Indeed, the North American science education programs and policies highlight that science education is inclusive and all individuals regardless of their gender, cultural background, social circumstances, and career aspirations have the abilities to develop scientific literacy (AAAS, 1993; Achieve, Inc., 2013; CMEC, 1997; MELS, 2007). The key goals of science education in North America emphasize that students should: (a) construct a deeper understanding of scientific concepts; (b) view science-related phenomena as a system of interconnected components that interact with one another; (c) reflect on their own construction of knowledge; (d) develop scientific reasoning and critically evaluate scientific ideas and socio-scientific issues; (e) formulate informed views and perspectives on issues of local and global importance, and (f) appreciate the history of science (Achieve, Inc., 2013; MELS, 2007).

In our science-driven modern society, these goals are of particular significance for all individuals to make sense of the intersections between scientific developments and their social lives. However, these goals might not be reaching many individuals with learning disabilities in Canadian schools. According to the Learning Disabilities Association of Canada (2002), learning disabilities result from:

impairments in one or more processes related to perceiving, thinking, remembering or learning. These include, but are not limited to: language processing; phonological processing; visual spatial processing; processing speed; memory and attention; and executive functions (e.g. planning and decision-making). (Official Definition of Learning Disabilities, 2002, para. 1-2)

Scholars and practitioners suggest that learning science might benefit students with learning disabilities (LD) as they "find ways to compensate for their problems by taking advantage of the interactive nature of instructional approaches in science education" (Carlisle \& Chang, 1996, p. 20). Thus, science education presents a valuable opportunity to socially include students with LD in mainstream science classrooms, yet it appears to be a missed opportunity in many K-12 settings. Therefore, in this article, we present a critical review of research on intervention practices in science education to support students with LD. Furthermore, we draw on the Universal Design for Learning (UDL) model, which emphasizes multiple means of representation, engagement, and assessment to offer a framework to enrich and differentiate science instruction for diverse learners. Specifically, we embed the UDL framework with inquiry-based practices that have been gleaned from our analysis of the relevant literature. Science inquiry-based approaches that involve students in formulating questions, making and 
testing predictions, developing hypotheses, collecting data, and drawing inferences, have shown to improve engagement and learning when compared to lecture-based traditional teaching approaches (Colburn, 2008; Geier et al., 2008; Hmelo-Silver, Duncan, \& Chinn, 2007).

However, reports of the National Assessment of Educational Progress (NAEP) lament the low academic achievement of students in science in North America. These documents indicate that students with disabilities-including those with LD-in elementary and secondary grades are lagging behind in science as evidenced by their significantly lower academic scores compared to their typically achieving peers (National Center for Education Statistics, 2005). Indeed, the persistently perplexing performance of students with LD might indicate that - contrary to the vision of science education programs and policies_-science is not accessible to all students. Surprisingly, despite significant advancements in research and movements towards inclusion of students with LD in science classrooms, recent studies have shown that stereotypes towards these students remain persistent among their teachers and peers. For example, science teachers tend to have lower academic expectations, and negative perceptions of them, due to the "LD label" that is often imprinted on them. Approximately 56\% of science teachers acknowledged that they use disability of students as an excuse for explaining the students' failure and around $79 \%$ of teachers reported the need for special training to overcome prejudices and emotional barriers while working with students with disabilities (Norman, Caseau, \& Stefanich, 1998). Moreover, in the wake of increasing numbers of students with LD in their classrooms, Canadian teachers have also reported their incessant challenges and struggles to support diverse learners in science (Caron, 2010; CBC News, 2010).

In addition, research suggests that typically achieving peers tend to have highly negative attitudes towards students with disabilities (Houck, Asselin, Troutman, \& Arrington, 1992; May \& Stone, 2010; Shapiro \& Margolis, 1988). Shapiro and Margolis (1988) observed that both teachers and typically achieving peers perceived students with LD as "dumb, lazy, spoiled, and hopeless" (p. 133). Recently, May and Stone (2010) also reported that typically achieving students regarded their peers with LD as not intelligent and lacking abilities to succeed academically. Because of the low acceptance level by their typically achieving peers and teachers, students with LD feel alienated from their classroom community and are more likely to develop low academic selfconcept (Pijl \& Frostad, 2010), lower academic self-efficacy, higher levels of anxiety (Hampton \& Mason, 2003), and higher levels of loneliness and negative moods (Lackaye \& Margalit, 2006). From a cognitive perspective, students with LD exhibit particular difficulties in retrieving prior knowledge, making observations, generating 
hypotheses, making predictions, and applying constructed knowledge to new contexts as compared to their typically achieving peers (Mastropieri, Scruggs, Boon, \& Carter, 2001; Mastropieri, Scruggs, \& Butcher, 1997; Mastropieri \& Scruggs, 1994). Clearly, due to these innumerable barriers, science may not be easily accessible to students with LD as compared to their typically achieving peers.

While students with LD have gained physical access to the general education classrooms, concerns about gaining access to the curriculum in the "inclusive" classrooms have been raised by several scholars and practitioners in the field (Edyburn, 2010). The ultimate task of enabling inclusion of students with LD in science classrooms seems to fall mainly in the hands of inexperienced instructors who lack a deeper understanding and knowledge of the characteristics of diverse learners (Norman, Caseau, \& Stenafich 1998; Scruggs, Brigham, \& Mastropieri, 2013). Therefore, it is critical that educators develop insightful understanding of inclusion and associated practices to offer meaningful learning opportunities to all students to develop a sophisticated understanding of science and its applications in everyday life.

Contrasted with the term "integration," which refers to a fixed state of homogeneity limited to granting access to the physical environment of classroom, "inclusion" is more complex and dynamic as it involves listening to hidden and unfamiliar voices; being open to abilities, ethnicities, and cultures; and empowering all members of the classroom community (Barton, 1998; Blamires, 1999; Edyburn, 2010). More precisely, inclusion involves teaching students with diverse needs in general education classrooms by providing differentiated adaptations and accommodations to facilitate student learning (Idol, 2006; Mastropieri \& Scruggs, 2000; Voltz, Sims, Nelson, \& Bivens, 2005). Students' academic and social growth are supported by enacting differentiated curricula, teaching/learning practices, and assessment strategies that are flexible, open, intellectually stimulating, and equitable to meet the multiple and unique needs of each learner (Rose, 2000; Rose \& Meyer, 2002).

\section{Conceptual Model for Inclusion: Universal Design for Learning}

Coined from the Americans with Disabilities Act in 1990, which focused on modifying the physical environment and architecture in public and private spaces for more accessibility to individuals with disabilities (e.g., increased elevator accessibility), the Universal Design for Learning highlights the "architecture of instruction" in curriculum 
design (Kameenui \& Simmons, 1999). This approach emphasizes cognitive access to students with disabilities where curriculum materials are constructed and restructured to differentiate instruction in response to the needs of diverse learners. Building on these perspectives, the Center for Applied Special Technology (CAST, 2011) was the first to postulate the term "Universal Design for Learning," which is grounded in cognitive neuroscience research (Rose, 2000; Rose \& Meyer, 2002).

The UDL model is based on three networks in our brains: recognition, strategic, and affective. Located in the posterior half of the brain's cortex, the recognition network is involved in making sense of and recognizing patterns in our daily lives (Rose, Harbour, Johnston, Daley, \& Abarbanell, 2006). For example, the patterns of falling leaves might indicate change in seasons. Pattern recognition is constructed through a multitude of stimuli, namely visual, auditory, tactile, and olfactory. Impairment of the recognition network renders pattern recognition very challenging - for example, individuals with dyslexia experience difficulties in recognizing patterns in written words (Bruck, 1990; O'Brien, Wolf, Miller, Lovett, \& Morris, 2011; Rose et al., 2006). Equally important, the anterior part of the brain (the frontal lobes) comprises the strategic network which deal with executive functioning that enables individuals to plan, organize, and execute actions. Deficits in these areas of the brain affect an individual's ability to plan and execute multiple tasks, which are particularly important in inquiry-based learning activities in science education. The affective component of the brain is located within the limbic system, which is responsible for our emotions and affects the ways in which we perceive our world. As discussed by Rose et al. (2006), "damage to the affective networks can impair the ability to establish priorities, select what we value or want, focus attention, or prioritize actions" (p. 139).

The UDL approach attempts to compensate for cognitive deficits and capitalize on cultural and social strengths of diverse learners in their construction of scientific knowledge. In particular, three main principles of UDL-multiple ways of representation, engagement, and expression-have been emphasized to support students in their cognitive development (Rose, 2000; Rose \& Meyer, 2002; Rose et al., 2006). The UDL model encourages inclusion of all individuals by allowing for multiple instructional and assessment practices to scaffold active knowledge construction through multiple means. In addition, these UDL principles seem to capitalize on strengths of students with LD rather than focusing on their cognitive deficits. Using this approach, teachers could construct equitable and inclusive learning environments for individuals with disabilities where they feel safe to engage in learning instead of feeling segregated and stigmatized. These inclusive practices might also support diverse students in developing their self-confidence while communicating their ideas on science with 
their teachers and peers. Below, we present the main principles and specific practices of UDL.

\section{Multiple Means of Representation}

There is no one way to "teach students how to work with information, including finding, creating, using, and organizing information" (Rose et al., 2006, p. 137). The UDL design stresses the importance of: (a) providing different options for perceiving and making sense of information (e.g., options that provide information through auditory, visual, and tactile modes); (b) providing differentiated options to support comprehension (e.g., options for decoding text, mathematical notations, and symbols); and (c) providing options to support conceptual understanding (e.g., options that can activate prior knowledge and to enable students to find patterns and build relationship among concepts) (CAST, 2011). Multiple means of representation are thus key to develop a meaningful understanding of scientific concepts by students.

\section{Multiple Means of Engagement}

The UDL approach also encourages educators to employ multiple means of engagement to: (a) trigger and sustain interest (e.g., engaging students in active learning experiences and providing options to minimize distractions); (b) maintain effort and persistence through cooperative learning (e.g., designing peer-based activities to foster collaboration and communication); and (c) encourage self-regulation (e.g., different types of self-assessments, reflections, learning and coping strategies) (CAST, 2011).

As also highlighted by Rose et al., (2006), not all students are motivated by similar extrinsic rewards, such as academic scores and grades. To deepen students' understanding of science concepts and their application to daily lives, multiple forms of engagement should be designed to motivate students to learn science, which could span inquiry-based learning experiences, cooperative learning, and case studies to encourage critical thinking and reflections. Through inquiry-driven activities, teachers can employ several alternative strategies to motivate diverse students to ask questions, conduct observations, test their predictions, construct hypotheses to explain natural phenomena, and communicate those ideas to others. While teachers play a key role in students' learning, collaborative actions in different inquiry-based activities among peers also lead to meaningful construction of scientific knowledge. Viewed as a community, students and teachers work together, exchange ideas, and learn from one another through the mediation of language, community, culture of speech, and 
practical activity which lead to multiple ways of making sense of scientific concepts during inquiry. In the inquiry-based classroom community, activities can be planned by teachers with emphasis on collaboration and social interaction to enact numerous possibilities for students to explore, construct, negotiate, and share their ideas.

\section{Multiple Means of Expression}

To offer students with opportunities to demonstrate their learning and understanding of concepts, teachers might employ multiple means of expression using a variety of creative ways to elicit and track students' emerging understandings. To this end, the UDL guiding principles recommend different types of assessments involving: (a) physical actions (e.g., employing multiple methods for response and navigation by using manipulatives, such as keyboards, or joysticks, etc.); (b) creative expressions and communication (e.g., offering multiple tools, such as text, videos, poetry, role-play, dance for construction and communication of knowledge); and (c) executive functions (e.g., providing structured and differentiated supports, such as graphic organizers and templates for setting goals, planning, and strategy development) (CAST, 2011).

Rich and creative inquiry-based activities in science provide students with numerous opportunities for expression. In terms of physical actions, they manipulate various tools to make sense of science concepts - for example, to comprehend the properties of solids, liquids, and gases, students can use blocks, clay, oil, water, syringes, balloons, and so forth. Students can communicate their understanding of the properties of these different states of matter through drawings, argumentations, and movement to imitate the motions of atoms and molecules within each state of matter. In terms of executive functions, students can plan, execute, and conduct experiments where teachers can use differentiated supports, such as inquiry-design protocols to scaffold their inquiry process. Through collaborative inquiries, students are given opportunities to stop, think, and assess the differentiated procedures to conduct experiments through discussions with their peers. 


\section{From Theory to Research: Using the UDL Framework to Examine Intervention-Based Research Strategies for Inclusion of Science Students with LD}

In this section, we examine intervention-based research studies with students with LD in science classrooms to develop a comprehensive understanding of the effectiveness of these practices in favouring inclusion. By drawing from the abovediscussed multiple means of representation, engagement, and expression, we discuss a few pertinent studies that examined the impact of differentiated instructional strategies on the learning, achievement, and engagement of students with LD.

\section{Inquiry-Based Activities for Inclusion of Students with LD}

Various studies have examined the impact of inquiry-driven teaching approaches on academic achievement and attitudes of students with LD towards learning (Bay, Staver, Bryan, \& Hale, 1992; Cawley, Hayden, Cade, \& Baker-Kroczynski, 2002; Mastropieri et al., 1998; Mastropieri et al., 1997; Mastropieri et al., 2001; McCarthy, 2005; McCleery \& Tindal, 1999; Scruggs, Mastropieri, Bakken, \& Brigham, 1993). Most of these studies have also compared the merits of inquiry-based teaching to direct instruction, which entails direct transmission of knowledge from the teacher to students with little to no exploration on the part of students. Direct instruction, synonymous to a "one-size-fitsall" instructional approach, fails to take into account diverse abilities in the classroom community, and has shown to have adverse effects on students' motivation and engagement in science (Osborne \& Collins, 2000; Osborne, Simon, \& Collins, 2003).

Hands-on practices, on the other hand, de-emphasize excessive dependence on textbooks, favour learning through multi-sensory modes, and are beneficial for students who face difficulties in reading and workbook assignments (Scruggs et al., 1993). In addition, students experiencing challenges in observing, reasoning, processing, retaining information, and critical thinking-essential skills in daily life and at work - can develop these skills through active engagement in inquiry-driven science activities (Adelman \& Vogel, 1990; Mastropieri \& Scruggs, 1992). Moreover, inquiry-based learning situations and experiences might lead to sustained attention, which would be promising for students with attention-deficit issues. Inquiry-driven approaches may also enhance meaningful science learning by drawing connections between students' lives and scientific models (Mastropieri \& Scruggs, 1998). 
McCarthy (2005) conducted a study to compare the performance of students with disabilities in inquiry-based and direct instruction programs. In this study, students who participated in inquiry-oriented activities demonstrated higher improvements in academic scores as compared to those who received instruction directly from the teacher. To construct their understanding about physical and chemical changes in matter, students were asked to bake a cake. By combining several ingredients, students observed physical and chemical changes during the baking process of the cake. Such an approach allowed students to experience learning in various multi-sensory fashions rather than listening to lectures and observing teacher's demonstrations. In addition to multiple means of representation and engagement, students were offered different modes of expression to demonstrate their knowledge through hands-on tasks, multiple-choice items, and questions that required short and long answers. In this study, the differentiated supports and activities provided multisensory, and multiple forms of, representation, engagement, and expression, which allowed the students to capitalize on their strengths, rather than focusing on their disabilities. As previously established by Bay and colleagues (1992), when students with disabilities were exposed to inquiry-based constructivist learning approaches and multiple ways of assessments (hands on as well as text based), they outperformed their typically achieving peers. This evidence points to the benefits of the UDL approach to enact an environment that is supportive and conducive to meaningful learning of science.

In another study, Scruggs and collaborators (1993) compared the academic outcomes and motivation levels associated with an inquiry-based approach to a teacher-directed approach in their work with high school students with LD. Specifically, the study focused on physical and earth science concepts (magnetism and electricity; soil and minerals). Among the various activities, students were engaged in the construction of circuits using motors and d-cells; they also constructed switches to control the flow of electricity. Other activities involved learning about how the strength of an electromagnet can be increased by increasing the number of coils wrapped around the magnet. While this study has drawn on multiple means of representation and engagement to promote learning for students with LD, only a single means of expression-oral interrogationwas employed to assess students' learning. Similar to this study, other studies (see Mastropieri et al., 2001) have employed only a single method of assessment to examine students' understanding of science concepts, whereas for representation and engagement, multiple activities were employed. In these studies (Scruggs et al., 1993; Mastropieri et al., 2001), the academic scores of students with disabilities were significantly lower than their typically achieving peers. Perhaps, if multiple and diverse choices are offered to students with LD to demonstrate what they had learned, they might have felt more confident to express their conceptual comprehension. 
While inquiry-based activities certainly benefit students with LD because of the multiple ways of representing science learning, other strategies have also been investigated to address the learning issues that students with LD continuously face in their science classrooms.

\section{Differentiated Curriculum Enhancements: Mnemonics and Graphic Organizers}

Students with LD who experience verbal memory deficits, difficulties in recalling scientific vocabulary, reading comprehension, identifying main ideas and key elements, and encounter problems in organizing information into more coherent units, might benefit from differentiated curriculum enhancements, such as mnemonics and graphic organizers. As emphasized by several studies, mnemonic strategies permit ways in which students can encode constructed knowledge that can be retrieved during testing (Levin, 1983; Mastropieri, Scruggs, \& Levin, 1985; Mastropieri, Scruggs, \& Levin, 1987; Scruggs \& Mastropieri, 2000). As Scruggs and Mastropieri (2000) explain, the importance of memory for retrieving prior knowledge during the construction of new scientific knowledge and teaching students how and what to remember is crucial. Various researchers argue the merits of mnemonic devices-often pictures and visual images, such as pictorial mnemonics or keywords-in learning extensive scientific vocabulary by transforming words into more meaningful representations (King-Sears, Mercer, \& Sindelar, 1992; Mastropieri, Scruggs, \& Levin, 1985; Mastropieri, Scruggs, \& Levin, 1986). For example, in biology, students need to learn new vocabulary terms, such as ranidae, the scientific term for common frogs. Scruggs and Mastropieri (2000) suggest using the keyword "rain" and showing a picture of frogs in the rain. Students can be asked specific questions to construct their understanding about frogs and rain, and then associate the scientific term ranidae to frogs.

In addition to mnemonics, graphic organizers provide an alternative format to help students with LD understand science texts. Graphic organizers effectively allow students to make sense of unfamiliar content, abstract concepts, and vocabulary acquisition-especially for students with LD experiencing major challenges in reading and comprehending texts (Bos \& Vaughn, 2002; Dexter, Park, \& Hughes, 2011; Hughes, Maccini, \& Gagnon, 2003; Ives \& Hoy, 2003; Kim, Vaughn, Wanzek, \& Wei, 2004; Nesbit \& Adesope, 2007; Rivera \& Smith, 1997). With visual and spatial displays, graphic organizers facilitate the construction of relationship between related concepts and facts. In this way, not only are abstract concepts represented more concretely, but understanding and retention of new concepts is also facilitated (Ausubel, 1968; Dexter \& Hughes, 2011; Gajria, Jitendra, Sood, \& Sacks, 2007; Hughes et al., 2003; Kim et al., 2004; Mayer, 1979). 
Despite the effectiveness of these organizational tools in a number of studies, other researchers did not demonstrate that mnemonics and graphic organizers improve learning for students with disabilities (see Dexter et al., 2011). It is only reasonable to assume that these techniques might not be sufficient to address the academic needs of all students. As stipulated by UDL principles, to instill inclusive instructional practices in K-16 classrooms, multiple means of representation need to be employed, which take into account students' diverse cognitive abilities and present learning materials through various stimuli-tactile and auditory-in addition to visual tools, such as mnemonic devices and graphic organizers.

\section{Multiple Approaches: Combining Peer-Assisted Tutoring and Differentiated Curriculum Enhancements}

A sparse number of studies have also investigated the merits of combining several strategies to support students with LD, some of whom are often off-task and have behavioural problems. These few studies have merged differentiated curriculum enhancement materials, such as mnemonics and board games related to science concepts, with collaborative learning strategies (peer-assisted instruction) to create a flexible and inclusive environment for diverse communities of learners (Mastropieri et al., 2006; Simpkins, Mastropieri, \& Thomas, 2009). An example is Mastropieri, Scruggs, and Graetz's (2005) study on academic and attitudinal outcomes of high school students with and without LD using peer tutoring with differentiated materials (cue cards with mnemonic-based visual images) in a chemistry lesson. Additionally, student outcomes in the differentiated curriculum were compared to their performance in teacher-directed instruction. In the peer-tutoring condition, students worked in pairs with cue cards that contained questions as well as prompts and elaborate explanations of chemistry concepts. For example, the question, "What is a mole?" is answered as the atomic weight in grams of an element or compound. If a student did not answer the question correctly, a peer-tutor would prompt the student (e.g., your weight in grams is?). If this strategy proved unsuccessful, then the tutor asked the student to think about the word "mole" and then a picture of a mole (the animal) on a scale checking its weight in grams was shown to the student, which is a visual tool to remember the information. Still, even with this strategy, students with LD obtained significantly lower scores on recall and comprehension as compared to their typically achieving peers. However, the authors reported that students' engagement and motivation levels were enhanced during collaborative learning with the differentiated chemistry curriculum. 
Our analysis of research-based differentiated interventions in science indicates that although several researchers employed multiple ways of representation and engagement, most studies lacked diversity in their assessment methods to examine students' understanding of science concepts.

\section{From Research to Practice: Application of UDL to Create Inclusive Science Practices}

The UDL approach seems promising for engaging students and favouring learning in multiple ways in science. Therefore, we adapted this model to develop an inclusive framework for science teaching and learning for diverse learners-especially those with LD. To this end, we draw from prior studies in science education focusing on students with LD, discussed in the previous section, to include effective practices that might foster learning and engagement of students with LD. Because the UDL model is currently being adopted to guide supportive strategies and programs for students with LD and other diverse learners at a number of colleges and universities in Quebec, our model seeks to inform science instruction and learning in advanced secondary and post-secondary classrooms. Specifically, we have adapted and expanded the UDL framework (CAST, 2011) with inquiry-oriented and problem-based approaches to support student engagement in science, facilitate meaningful scientific literacy, and provide opportunities for multiple means of expression.

While it is crucial to understand the unique learning barriers that students with LD might face due to their cognitive deficits, it is equally important to gauge the alternate conceptions or intuitive ideas that students bring to the classroom to develop effective strategies for a comprehensive understanding of science concepts (Asghar, 2011; Libarkin, Asghar, Crockett, \& Sadler, 2011; Hawbaker, Balong, Buckwalter, \& Runyon, 2001). Research suggests that children's intuitive ideas constitute localized explanatory models that are fairly resistant to change, particularly through direct and lecturebased instructional methods (Asghar, 2004, 2011; Asghar \& Libarkin, 2010; Driver, 1985; Shapiro, 1994; Stead \& Osborne, 1980). Therefore, effective science instruction for conceptual change should be oriented towards constructing learning situations where students' existing intuitive or novice cognitive structures are challenged to scaffold them in building new representations of the natural world based on accepted scientific models. For example, children — and many adults - tend to think that air has no mass. In order to address this deeply held intuitive idea, teachers could design inquiry-based activities where students can make predictions about the mass of air and then conduct investigations to test their predictions. Through active engagement in hands-on inquiries and by collecting relevant data about the mass of air, students would observe 
and (re)construct their models by reflecting on the new evidence gathered during the inquiry, and alter their representations to conclude that air has mass. Therefore, science teachers need to identify the unique intuitive ideas that students with LD bring to their science classrooms.

Unfortunately, teachers are still struggling to find ways to maximize participation of all learners to construct meaningful scientific knowledge and understanding. The problems faced by teachers might worsen as the number of students with LD is likely to increase in general education classrooms. Therefore, it is crucial for science teachers to transform their practices and employ differentiated tools to enhance engagement and learning. To further support teachers to promote inclusive practices in science classrooms, we draw from the UDL model and science education practices to propose a framework to scaffold cognitive, affective, and social growth of students with LD within an inclusive science classroom.

\section{Using Multisensory Means of Representation in Science Teaching and Learning}

Firstly, science educators need to focus on multisensory means to present big ideas in science. Equally essential is to select key foundational concepts that are relevant to the big ideas from the science curriculum (Hawbaker et al., 2001). Big ideas are "major organizing principles" and concepts that have rich explanatory and predictive power, and are applicable to many situations and contexts (Carnine, Dixon, \& Silbert, 1998). Big ideas are important because all individuals, irrespective of their abilities, beliefs, and ethnicity, need to draw on them in their daily lives, while attempting to make sense of the natural world (AAAS, 1993; Achieve Inc., 2013; CMEC, 1997; MELS, 2007).

To create an inclusive environment that meets the individual academic needs of all learners, students should be encouraged to make mistakes and learn from their failure as "real" scientists do in their practice. In order to support students with LD, teachers must enact safe and supportive learning environments that allow all science students to participate freely without the fear of being judged by their teachers and peers. Using multiple means of representation, science teachers can engage their students to experience and learn about the natural world in multisensory ways. For example, the following strategies and tools could be used to differentiate the science curriculum and teaching/learning practices.

Tactile. Employ concrete physical materials and manipulatives for demonstrations and student-led inquires (e.g., 3D models, role-play, lab tools). 
Visual. Use a variety of visual tools (e.g., graphic organizers), What I Know, what I Want to know, what I Learned (KWL) charts, animations, simulations, videos, interactive presentations.

Auditory. Use auditory stimuli, such as audiotaped presentations, podcasts summarizing key concepts and big ideas.

As conceptual development entails assimilation of new representations and a substantial reorganization of intuitive ideas (accommodation), eliciting and building on students' intuitive models is a significant goal of science learning. Therefore, it is crucial that teachers use multiple means to probe and represent students' intuitive models before and during instruction. For example, students' preconceptions and intuitive ideas can be elicited through drawings, multiple-choice questions, and conversations with students to explore how they have understood taught concepts. Because students with LD might struggle to process and organize information, science educators need to provide extra time to these students to represent their thinking and prior knowledge.

To illustrate the application of this framework to science teaching, we offer a specific example related to the concept of biomolecules as shown in Table 1. Biomolecules are utilized by living organisms and include large macromolecules such as proteins, polysaccharides, lipids, and nucleicacids_-for example, glucose is a familiar biomolecule. We selected the concept of biomolecules because it spans across many science courses (e.g., biology, biochemistry, nutrition) in high school to post-secondary education. Through visual representations (e.g., drawing biomolecules and online animations), students might develop a clearer understanding of the differences in the structures of different biomolecules. Some students might prefer a more tactile approach such as role-playing rather than drawing. In this case, teachers might assign students to take the roles of carbon, hydrogen, and oxygen atoms and ask them to model the structure of a biomolecule, such as glucose in its linear and cyclic form. Moreover, by using play dough and other art-based supplies, students can construct and compare 3-D structures of different biomolecules, allowing them to better visualize the positioning of atoms and types of bonding between different biomolecules.

\section{Using Multisensory Means of Engagement in Science Learning Experiences}

Providing various options to encourage active engagement and enhance student motivation is also vital while learning science. Designing active learning experiences through hands-on inquiries, reflection on observations, collaboration, and cooperative 
learning can engage learners with LD while minimizing distractions. Science teachers could particularly consider the following strategies to provide multisensory means of engagement:

Hands-on and minds-on inquiries. Design inquiries to promote conceptual learning through developing predictions, planning investigations to test predictions, collecting data, and constructing evidence-based explanations to develop a deeper understanding of scientific concepts.

Self-regulation. Support students to establish clear learning goals and develop strategies to monitor their attention, progress, and learning in relation to their own goals.

Self-reflection and assessment. Encourage students to reflect on their learning by using structured protocols or worksheets, writing journals, keeping audio diaries, sharing their understanding of science concepts with peers, and identifying areas for improvement through conversations with teachers.

Altogether, students should be given rich opportunities to challenge their existing constructs -intuitive conceptions or alternate understandings - to facilitate the development of new representations and reconstruction of intuitive ideas. For example, to develop a clear concept of biomolecules, teachers can ask their students to list multiple foods of their choice and ask them whether these foods can be classified mainly as carbohydrates, proteins, or lipids. In groups, students can debate the reasons that led them to classify foods accordingly. Students' preconceptions or alternate conceptions could be elicited through a series of questions, conversations, and constructive argumentation by science teachers. A clear awareness of students' intuitive ideas would help the teachers to guide them in developing their questions for inquiries, predictions, and designing experiments to test them. Students should be encouraged to develop their explanations based on the data obtained through their inquiries. At the same time, teachers need to develop structured assessment strategies and tools to further probe and keep track of their students' emerging models of biomolecules (e.g., worksheets, students' response sheets, multiple assessment items, rubrics, KWL charts, etc.). Using peer-based activities, teachers can encourage the students to work collaboratively to "discover" the different biomolecules in food samples or "unknown solutions" by designing inquiries to test their predictions. In Table 1, we present different means of engagement. 


\section{Using Multisensory Means of Expression to Demonstrate Science Learning}

While inquiry-based activities engage students in multimodal science learning, a spectrum of assessment strategies-both formative and summative-are crucial to elicit and track students' thinking and emerging understanding. Below, we present some means of expression for students to demonstrate their knowledge and comprehension.

Performance-based assessments in science. Use authentic and real-life problems to encourage students' problem-solving abilities. For example, encourage students to design and conduct inquiries_-independently or with their peers - to test their ideas and explanations.

Diverse assessment tools. Employ a variety of assessments before, during, and after instruction to track students' models and learning trajectories, for example, multiplechoice questions, short essays, worksheets, drawings, poster presentations, and podcasts to share findings/data. Different means of expression such as written work (e.g., journals, reflective diaries, lab reports); oral presentations; case studies and visual means of assessment should be given equal importance and consideration alongside more formal science exams and tests. Focusing on only one type of assessment might be inadequate in conveying a richer and comprehensive understanding of these concepts. Particularly significant for students with LD, multiple forms of expression draw from students' strengths and skills to demonstrate their constructed knowledge as shown in Table 1 for biomolecules. Because the objectives of science education are mainly geared towards developing critical thinking, reasoning, and problem solving-essential life skills-multiple means of expression, such as performance-based assessments and case studies, can be used to assess these skills.

\section{Conclusion}

Promoting inclusion by using these multiple modes and means to support diverse students' learning of science might seem a complex and daunting task. As more emphasis is being placed on educating diverse learners in general science classrooms, science educators need to be equipped with ideas, tools, and necessary support to create safe and inclusive spaces for collaborative learning. Thus, it is crucial to integrate such practices in teacher preparation and continuing professional development programs. In this paper, we presented an inclusive science education framework drawn from UDL principles and evidence-based practices in science education for 
students with LD to offer some practical ideas and tools to support academic needs of these diverse learners. Further research is required to explore the effectiveness of differentiated means of representation, engagement, and expression to make science accessible to diverse learners.

\section{Table 1}

Making Sense of Biomolecules Through Multisensory Means of Representation, Engagement, and Expression

\begin{tabular}{|c|c|c|}
\hline $\begin{array}{c}\text { Multisensory Means of } \\
\text { Representation }\end{array}$ & $\begin{array}{c}\text { Multisensory Means of } \\
\text { Engagement }\end{array}$ & $\begin{array}{c}\text { Multisensory Means of } \\
\text { Expression }\end{array}$ \\
\hline $\begin{array}{l}\text { Visual } \\
\text { - Asking students to draw } \\
\text { and make concept maps } \\
\text { to articulate their } \\
\text { preconceptions or intuitive } \\
\text { models of biomolecules } \\
\text { - Drawing biomolecules and } \\
\text { comparing the differences } \\
\text { in their structure. Example: } \\
\text { drawing of simple sugars- } \\
\text { monosaccharides such } \\
\text { as fructose, glucose, and } \\
\text { galactose and using different } \\
\text { colours to represent carbon, } \\
\text { hydrogen, and oxygen } \\
\text { molecules } \\
\text { - View online animations and } \\
\text { simulations } \\
\text { - Slides/charts/notes with } \\
\text { images and concept maps } \\
\text { on differences between } \\
\text { biomolecules } \\
\text { - Tactile } \\
\text { - Using play dough and } \\
\text { art-based supplies to model } \\
\text { bonding in biomolecules } \\
\text { biomolecules }\end{array}$ & $\begin{array}{l}\text { Hands-on and Minds-on } \\
\text { Inquiries } \\
\text { - Asking questions to probe } \\
\text { students' preconceptions or } \\
\text { alternate understandings } \\
\text { such as: } \\
\text { - What types of food can } \\
\text { be mainly classified as } \\
\text { carbohydrates? } \\
\text { - What are the reasons } \\
\text { or experiences you } \\
\text { have used to classify } \\
\text { these types of food as } \\
\text { carbohydrates? } \\
\text { - Conducting inquiries: } \\
\text { laboratory sessions focused } \\
\text { on conducting experiments } \\
\text { to differentiate different } \\
\text { biomolecules (proteins and } \\
\text { carbohydrates). Chemical } \\
\text { tests (e.g., Benedict test) } \\
\text { can be used to differentiate } \\
\text { between different types of } \\
\text { sugars (e.g., monosaccharides } \\
\text { and disaccharides) }\end{array}$ & $\begin{array}{l}\text { Diverse Assessment Tools } \\
\text { - Written: Worksheets, } \\
\text { conceptual journals, lab } \\
\text { reports, diaries, KWL charts, } \\
\text { concept maps } \\
\text { - Students can write } \\
\text { about their favourite } \\
\text { biomolecules, explaining } \\
\text { the relationship between } \\
\text { structure and function. } \\
\text { They can also articulate } \\
\text { the benefits and adverse } \\
\text { effects of different } \\
\text { biomolecules on their } \\
\text { health } \\
\text { - Oral: Oral presentations } \\
\text { on concepts involving } \\
\text { biomolecules (e.g., poster } \\
\text { presentations) }\end{array}$ \\
\hline
\end{tabular}


Table 1

Making Sense of Biomolecules Through Multisensory Means of Representation, Engagement, and Expression (cont.)

\begin{tabular}{|c|c|c|}
\hline $\begin{array}{c}\text { Multisensory Means of } \\
\text { Representation }\end{array}$ & $\begin{array}{c}\text { Multisensory Means of } \\
\text { Engagement }\end{array}$ & $\begin{array}{l}\text { Multisensory Means of } \\
\text { Expression }\end{array}$ \\
\hline $\begin{array}{l}\quad \text { Auditory } \\
\text { - Audio taping discussions in } \\
\text { classes on concepts } \\
\text { - Developing podcasts on key } \\
\text { concepts }\end{array}$ & $\begin{array}{l}\text { Self-Regulation, } \\
\text { Self-Reflection, and } \\
\text { Self-Assessment } \\
\text { - Students can set up their own } \\
\text { learning goals with teachers' } \\
\text { support and reflect on their } \\
\text { work and progress in relation } \\
\text { to those goals (e.g., using } \\
\text { checklists and self-reflective } \\
\text { audio-diaries) } \\
\text { - Peer-based activities where } \\
\text { students are given an } \\
\text { unknown solution and tasked } \\
\text { to identify the different } \\
\text { biomolecules by asking } \\
\text { questions, formulating } \\
\text { hypotheses, testing, } \\
\text { observing, argumenting, } \\
\text { drawing conclusions } \\
\text { - Web-based activities: } \\
\text { virtual labs on biomolecules } \\
\text { (e.g., http://learni.st/ } \\
\text { learnings/44003-virtual-lab- } \\
\text { investigating-biological- } \\
\text { compounds) }\end{array}$ & $\begin{array}{l}\text { Performance-Based } \\
\text { Assessments } \\
\text { - Student-led authentic } \\
\text { hands-on activities to } \\
\text { demonstrate their critical } \\
\text { thinking, reasoning, problem } \\
\text { solving } \\
\text { - Case studies. For example, } \\
\text { students can be given a } \\
\text { case study on an individual } \\
\text { who is anorexic and asked } \\
\text { to diagnose and address } \\
\text { the problem using their } \\
\text { knowledge of biomolecules } \\
\text { and nutrition }\end{array}$ \\
\hline
\end{tabular}




\section{References}

Achieve, Inc. (2013). Next Generation Science Standards. Achieve, Inc. on behalf of the twenty-six states and partners that collaborated on the NGSS.

Adelman, P. B., \& Vogel, S. A. (1990). College graduates with learning disabilities-employment attainment and career patterns. Learning Disability Quarterly, 13, 154-166.

American Association for the Advancement of Science (AAAS). (1993). Benchmarks for Science Literacy, Washington, D.C., American Association for the Advancement of Science.

Asghar, A. (2004). Exploring children's cognitive and affective skills using Fischer's dynamic skills model. Unpublished doctoral dissertation. Harvard University.

Asghar, A. (2011). Differentiating science pedagogy. In F. Ornek and I. M. Saleh (Eds.), Contemporary science teaching approaches. Germany: VDM Publishing House.

Asghar, A., \& Libarkin, J. (2010). Gravity, magnetism, and 'down': College students' conceptions of gravity. The Science Education, 19(1), 42-55.

Ausubel, D. P. (1968). Educational psychology: $A$ cognitive view. New York: Holt, Rinehart, \& Winston.

Barton, L. (1998) Markets, managerialism and inclusive education. In P. Clough (Ed.), Managing inclusive education: From policy to experience. London: Paul Chapman.

Bay, M., Staver, J. R., Bryan, T., \& Hale, J. B. (1992). Science instruction for the mildly handicapped: Direct instruction versus discovery teaching. Journal of Research in Science Teaching, 29, 555-570.

Blamires, M. (1999). Universal design for learning: Re-establishing differentiation as part of the inclusion agenda? Support for Learning, 14(4), 158-163.

Bos, C. S., \& Vaughn, S. (2002). Strategies for teaching students with learning and behavior problems (5th ed.). Boston: Allyn \& Bacon.
Bruck, M. (1990). Word recognition skins of adults with childhood diagnoses of dyslexia. Developmental Psychology, 26, 439-454.

Carlisle, J. F., \& Chang, V. (1996). Evaluation of academic capabilities in science by students with and without learning disabilities and their teachers. The Journal of Special Education, 30, 18-34.

Carnine, D., Dixon, R. C., \& Silbert, J. (1998). Effective strategies for teaching mathematics. In E. J. Kameenui \& D. W. Carnine (Eds.), Effective teaching strategies that accommodate diverse learners (p. 95). Upper Saddle River, NJ: Merrill.

Caron, R. (2010). Le journal de Québec: Les «normaux» pénalisés. Retrieved from: http://lejournaldequebec.canoe.ca/journal dequebec/actualites/quebec/archives /2010/10/20101019-220935.html

Cawley, J., Hayden, S., Cade, E., \& BakerKroczynski, S. (2002). Including students with disabilities into the general education science classroom. Exceptional Children, 68, 423-435.

CBC News. (2010). Quebec to review special needs education. Retrieved from: http://www. cbc.ca/canada/montreal/story/2010/04/20/ quebec-special-needs-students.html

Center for Applied Special Technology (CAST). (2011). About UDL. Retrieved from: http:// www.cast.org/publications/UDLguidelines/ version1.html

Colburn, A. (2008). Making inquiry successful. The Science Teacher, 75(7), 12.

Council of Ministers of Education (CMEC). (1997). Common framework of science learning outcomes K-12. Victoria, BC, Ministry of Education, Skills and Training.

Dexter, D. D., Park, Y. J., \& Hughes, C. A. (2011). A meta-analytic review of graphic organizers and science instruction for adolescents with learning disabilities: Implications for the intermediate and secondary science classroom. Learning Disabilities Research \& Practice, 26, 204-213. 
Dexter, D. D., \& Hughes, C. A. (2011). Graphic organizers and students with learning disabilities: A meta-analysis. Learning Disability Quarterly, 34, 51-72.

Driver, R. (1985). Children's ideas in science. Milton Keynes, UK: Open University Press.

Edyburn, D. L. (2010). Would you recognize Universal Design for Learning if you saw it? Ten propositions for new directions in the second decade of UDL. Learning Disability Quarterly, 33(1), 33-41.

Feinstein, N. (2011). Salvaging science literacy. Science Education, 95, 168-185.

Gajria, M., Jitendra, A. K., Sood, S., \& Sacks, G. (2007). Improving comprehension of expository text in students with LD: A research synthesis. Journal of Learning Disabilities, 40 , 210-225.

Geier, R., Blumenfeld, P., Marx, R., Krajcik, J., Fishman, B., \& Soloway, E. (2008). Standardized test outcomes for students engaged in inquiry-based science curriculum in the context of urban reform. Journal of Research in Science Teaching, 45, 922-939.

Hampton, N. Z., \& Mason, E. (2003). Learning disabilities, gender, sources of efficacy, selfefficacy beliefs, and academic achievement in high school students. Journal of School Psychology, 41, 101-112.

Hawbaker, B. W., Balong, M., Buckwalter, S., \& Runyon, S. (2001). Building a strong BASE of support for all students through coplanning. Teaching Exceptional Children, 33(4), 24-30.

Hmelo-Silver, C., Duncan, R., \& Chinn, C. (2007). Scaffolding and achievement in problembased and inquiry learning: $A$ response to Kirschner, Sweller, and Clark (2006). Educational Psychologist, 42, 99-107.

Holbrook, J., \& Rannikmae, M. (2009). The meaning of scientific literacy. International Journal of Environmental \& Science Education, 4(3), 275-288.

Houck, C. K., Asselin, S. B., Troutman, G. C., \& Arrington, J. M. (1992). Students with learning disabilities in the university environment: A study of faculty and student perceptions. Journal of Learning Disabilities, $25,678-684$.
Hughes, C. A., Maccini, P., \& Gagnon, J. C. (2003). Interventions that positively impact the performance of students with learning disabilities in secondary general education classes. Learning Disabilities, 12, 101-111.

Idol, I. (2006). Toward inclusion of special education students in general education: A program evaluation of eight schools. Remedial and Special Education, 27, 77-94.

Ives, B., \& Hoy, C. (2003). Graphic organizers applied to higher-level secondary mathematics. Learning Disabilities Research \& Practice, 18, 36-51.

Kameenui, E.J., \& Simmons, D.C. (1999). Towards successful inclusion of students with disabilities: The architecture of instruction. Reston, VA: The Council for Exceptional Children.

Kim, A., Vaughn, S., Wanzek, J., \& Wei, S. (2004). Graphic organizers and their effects on the reading comprehension of students with LD: A synthesis of research. Journal of Learning Disabilities, 37, 105-118.

King-Sears, M. E., Mercer, D. D., \& Sindelar, P. T. (1992). Toward independence with keyword mnemonics: A strategy for science vocabulary instruction. Remedial and Special Education, 13, 22-33.

Lackaye, T. D., \& Margalit, M. (2006). Comparisons of achievement, effort, and self-perceptions among students with learning disabilities and their peers from different achievement groups. Journal of Learning Disabilities, 39, 432-446.

Learning Disabilities Association of Canada. (2002). Official definition of learning disabilities. Ottawa, Ontario: Author.

Levin, J. R. (1983). Pictorial strategies for school learning: Practical illustrations. In M. Pressley \& J. R. Levin (Eds.), Cognitive strategy research: Educational applications (pp. 213-237). New York: Springer-Verlag.

Libarkin, J. C., Asghar, A., Crockett, C., \& Sadler, P. (2011). Invisible misconceptions: Student understanding of ultraviolet and infrared radiation. Astronomy Education Review, 10(1), $1-25$.

Mastropieri, M. A., \& Scruggs, T. E. (1992). Science for students with disabilities. Review of Educational Research, 62, 377-411. 
Mastropieri, M. A., \& Scruggs, T. E. (1994). Text-based vs. activities oriented science curriculum: Implications for students with disabilities. Remedial and Special Education, 15, 72-85. doi: 10.1177/074193259401500203

Mastropieri, M. A., \& Scruggs, T. E. (1998). Enhancing school success with mnemonic strategies. Intervention in School and Clinic, 33, 201-208.

Mastropieri, M. A., \& Scruggs, T. E. (2000). Promoting inclusion in secondary classrooms. Learning Disability Quarterly, 24, 265-274.

Mastropieri, M. A., Scruggs, T. E., \& Butcher, K. (1997). How effective is inquiry learning for students with mild disabilities? The Journal of Special Education, 31, 199-211.

Mastropieri, M. A., Scruggs, T. E., \& Graetz, J. (2005). Cognition and learning in inclusive high school chemistry classes. In T. E. Scruggs \& M. A. Mastropieri (Eds.), Cognition and learning in diverse settings: Advances in learning and behavioral disabilities (Vol. 18, pp. 99-110). Oxford, UK: Elsevier.

Mastropieri, M. A., Scruggs, T. E., \& Levin, J. R. (1985). Mnemonic strategy instruction with learning disabled adolescents. Journal of Learning Disabilities, 18, 94-100.

Mastropieri, M. A., Scruggs, T. E., \& Levin, J. R. (1986). Learning disabled students' memory for expository prose: Mnemonic vs. nonmnemonic pictures. American Educational Research Journal, 24, 505-519. doi: 10.3102/00028312024004505

Mastropieri, M. A., Scruggs, T. E., \& Levin, J. R. (1987). Mnemonic instruction in special education. In M. A. McDaniel \& M. Pressley (Eds.), Imagery and related mnemonic processes: Theories, individual differences, and applications (pp. 358-376). New York: Springer-Verlag.

Mastropieri, M. A., Scruggs, T. E., Boon, R., \& Carter, K. B. (2001). Correlates of inquiry learning in science: Constructing concepts of density and buoyancy. Remedial and Special Education, 22, 130-138.
Mastropieri, M. A., Scruggs, T. E., Mantzicopoulous, P., Sturgeon, A., Goodwin, L., \& Chung, S. (1998). "A place where living things affect and depend on each other": Qualitative and quantitative outcomes associated with inclusive science teaching. Science Education, 82, 163-179.

Mastropieri, M. A., Scruggs, T. E., Norland, J., Berkeley, S., McDuffie, K., Tornquist, E. H., et al. (2006). Differentiated curriculum enhancement in inclusive middle school science: Effects on classroom and high-stakes tests. The Journal of Special Education, 40, 130-137.

May, A. L., \& Stone, C. A. (2010). Stereotypes of individuals with learning disabilities: views of college students with and without learning disabilities. Journal of Learning Disabilities, 43, 483-499.

Mayer, R. E. (1979). Can advanced organizers influence meaningful learning? Review of Educational Research, 49, 371-383.

McCarthy, C. B. (2005). Effects of thematic-based, hands-on science teaching versus a textbook approach for students with disabilities. Journal of Research in Science Teaching, 33, 245-263.

McCleery, J. A., \& Tindal, G. A. (1999). Teaching the scientific method to at-risk students and students with learning disabilities through concept anchoring and explicit instruction. Remedial and Special Education, 20, 7-18.

Ministère de l'Éducation, du Loisir et du Sport du Québec (MELS). (2007). Applied science and technology: Québec education program: secondary school education, cycle two. [Québec]: Éducation Québec.

National Center for Education Statistics. (2005). "NAEP Inclusion Policy." The Nation's Report Card. Retrieved from: http://nces.ed.gov/ nationsreportcard/about/inclusion.asp.

Nesbit, J. C., \& Adesope, O. O. (2006). Learning with concept and knowledge maps: A meta analysis. Review of Educational Research, 76, 413-448.

Norman, K., Caseau, D., \& Stefanich, G. P. (1998). Teaching students with disabilities in inclusive science classrooms: Survey results. Science Education, 82, 127-146. 
O'Brien, B. A., Wolf, M., Miller, L. T., Lovett, M. W., \& Morris, R. (2011). Orthographic processing efficiency in developmental dyslexia: an investigation of age and treatment factors at the sublexical level. Annals of Dyslexia, 61, 111-135.

Osborne, J. F., \& Collins, S. (2000). Pupils' and parents'views of the school science curriculum. London: King's College London.

Osborne, J., Simon, S., \& Collins, S. (2003). Attitudes towards science: A review of the literature and its implications. International Journal of Science Education, 25(9), 1049-1079.

Pijl, S. J., \& Frostad, P. (2010). Peer acceptance and self-concept of students with disabilities in regular education. European Journal of Special Needs Education, 25, 93-105.

Rivera, D. P., \& Smith, D. (1997). Teaching students with learning and behavior problems (3rd ed.). Boston: Allyn \& Bacon.

Rose, D. (2000). Universal design for learning: Associate editor column. Journal of Special Education Technology, 15(4).

Rose, D. H., \& Meyer, A. (2002). Teaching every student in the digital age: Universal design for learning. Alexandria, VA: Association for Supervision and Curriculum Development (ASCD). (Also available in digital format at http://www.cast.org).

Rose, D. H., Harbour, W. S., Johnston, S. C., Daley, S. G., \& Abarbanell, L. (2006). Universal design for learning in postsecondary education: Reflections on principles and their applications. Journal of Postsecondary Education and Disability, 19, 135-151.
Scruggs, T. E., Brigham, F. J., \& Mastropieri, M. A. (2013). Common core science standards: Implications for students with learning disabilities. Learning Disabilities Research \& Practice, 28, 49-57. doi: 10.1111/ldrp.12002

Scruggs, T. E., \& Mastropieri, M. A. (2000). The effectiveness of mnemonic instruction for students with learning and behavior problems: An update and research synthesis. Journal of Behavioral Education, 10, 163-173.

Scruggs, T. E., Mastropieri, M. A., Bakken, J. P., \& Brigham, F. J. (1993). Reading vs. doing: The relative effectiveness of textbook-based and inquiry-oriented approaches to science education. The Journal of Special Education, $27,1-15$.

Shapiro, A., \& Margolis, H. (1988). Changing negative peer attitudes toward students with learning disabilities. Reading, Writing, and Learning Disabilities, 4, 133-146.

Shapiro, B. (1994). What children bring to light. New York: Teachers College Press.

Simpkins, M. P., Mastropieri, M. A., \& Thomas, E. S. (2009). Differentiated curriculum enhancements in inclusive fifth-grade science classes. Remedial and Special Education, 30, 300-308.

Stead, K., \& Osborne, R. (1980). Gravity. A working paper of the learning in science project. Hamilton, New Zealand: University of Waikato, Science Education Research Unit.

Voltz, D. L., Sims, M. J., Nelson, B., \& Bivens, C. (2005). Mecca: A framework for inclusion in the context of standards-based reform. Teaching Exceptional Children, 37, 14-19. 


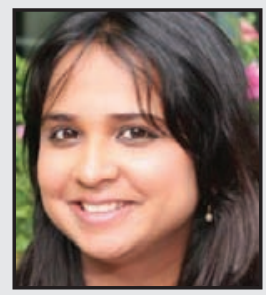

Neerusha Baurhoo is a PhD Candidate in the Department of Integrated Studies in Education at McGill University, where she also completed her Masters Degree in Animal Science. Her research focuses on teaching and learning practices for students with learning disabilities and special needs in STEM education. Her academic interests also include mixed-methods research approaches, inclusive practices, and intervention-based strategies with focus on students with special needs. Currently, she works at John Abbott CEGEP, differentiating science and math education for students with learning disabilities.

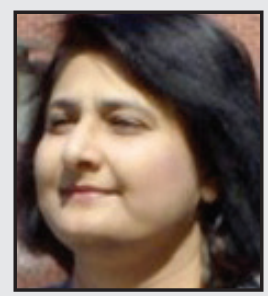

Anila Asghar is an Associate Professor in the Department of Integrated Studies in Education at McGill University. Prior to joining McGill she was an Assistant Professor at the Johns Hopkins School of Education. Her research focuses on cognitive and emotional development while learning science, conceptual change, and problem-based learning in science/ STEM education. She has also been looking at science education reform and the interactions among science, culture, and religion in diverse international contexts. 